\title{
Movements and habitat use of the invasive species Lithobates catesbeianus in the valley of the Grote Nete (Belgium)
}

\author{
Sarah Descamps ${ }^{1,2, *} \&$ Alain De Vocht ${ }^{1,2}$
}

\author{
1 PXL- Bio Research, Agoralaan Building H, BE-3590 Diepenbeek \\ 2 Hasselt University - Centre for Environmental Sciences, Agoralaan Building D, BE-3590 Diepenbeek \\ * Corresponding author: sarah.descamps@pxl.be; sarah.descamps@uhasselt.be
}

\begin{abstract}
Nine adult American bullfrogs (Lithobates catesbeianus) were tagged with an internal radio transmitter and tracked during one year in the valley of the Grote Nete (Belgium). The mean \pm SD core range area (KDE50) was $15.00 \pm 22.41 \mathrm{~m}^{2}$. The home range area (KDE95) had a mean $\pm \mathrm{SD}$ of $429.78 \pm 510.97 \mathrm{~m}^{2}$. Shores of larger eutrophic ponds and small temporary pools in alluvial forest were chosen as habitat. The total area used (MCP95) had a mean of $11,086.73 \pm 12,239.00 \mathrm{~m}^{2}$. The study revealed a mean action radius of $270.78 \pm$ $199.17 \mathrm{~m}$ and individuals moved up to $742 \mathrm{~m}$ in a single displacement. These results show that the dispersion of the American bullfrog in a valley system such as the Grote Nete can proceed very rapidly. A positive correlation between weight and distance covered within one movement was found, which could suggest that dominant individuals are capable of covering greater distances in search of optimal habitat for reproduction, foraging or hibernation.
\end{abstract}

KEY WORDS: invasive species, SAC, radio telemetry, American bullfrog, Rana catesbeiana

\section{INTRODUCTION}

Invasive species are a worldwide threat for native biodiversity and are a major cause of the extinction of species (CLAVERO \& GARCIABERTHOU, 2005). The American bullfrog (Lithobates catesbeianus SHAW, 1802) is listed on the IUCN's list of the world's hundred worst invasive alien species because of its invasive character and its ecological impact (LOWE et al., 2000).

The natural range of the American bullfrog spans a wide latitude, extending north to Canada (Nova Scotia, New Brunswick, southern Quebec and southern Ontario) and south to central Florida and north-eastern Mexico. This vast natural range illustrates the species' flexible life history and broad climatic and ecological amplitude, which contributes to its success as an invasive alien species (D'AMORE, 2012). In the $20^{\text {th }}$ century this species was introduced in aquaculture as a biological control agent or for ornamental purposes (JENNINGS \& HAYES,
1985). It has since then been partly responsible for the decline of populations of native species (ADAMS \& PEARL, 2007).

In Belgium the invasive exotic American bullfrog is widely spread in the valley of the Grote Nete, where the population inhabits over 400 ponds in an area of $100 \mathrm{~km}^{2}$. The valley of the Grote Nete is assigned as a Special Area of Conservation (SAC) for the Habitats Directive and consists of 4,280 hectares of alluvial forests, eutrophic ponds, marshes and mesotrophic meadows (AGENTSCHAP VOOR NATUUR EN Bos, 2012). Within this system the invasive American bullfrog has dispersed from its initial point of invasion (Zammelsbroek) upstream and downstream along the river Grote Nete.

The American bullfrog is an opportunistic feeder and feeds on larger invertebrates, fishes, indigenous amphibians, young reptiles and their own larvae and sub-adults (LEIVAS et al., 2012). This species is also a vector of the chytrid fungus Batrachochytrium dendrobatidis (LONGCORE, 
Pessier \&. Nichols, 1999). A recent study demonstrated that $63.4 \%$ of the adult bullfrogs and $20.5 \%$ of the larvae in Belgium are infected (PASMANS \& MARTEL, 2012). This chytrid fungus contributed to the total extinction of a population of amphibia in Brazil (SCHLOEGEL et al., 2010). The presence and abundance of this invasive species in the valley of the Grote Nete forms, consequently, a potential threat to local biodiversity in this European SAC.

The American bullfrog generally prefers still, deep water habitats with rooted floating vegetation and open shoreline vegetation (FULLER et al., 2010). Permanent wetlands form a possible indicator of both bullfrog occupancy and the presence of a reproducing population. Moreover, the distance of a wetland to the nearest lake or pond, as well as the amount of wetland area within a $1 \mathrm{~km}$-buffer, is positively associated with bullfrog presence. The occurrence of waterway corridors, whether or not human made, also favours the dispersion of this species across the landscape (PETERSON et al., 2013).

Local field data on the invasive bullfrog are fragmented but are important to evaluate the impact of this biological invasion. Knowledge of their local behaviour, dispersion rate and movements are essential to optimise control methods and actions. To gain a better insight into the activity, home range and dispersion of this species, a telemetric study in the upstream part of the valley was set up.

\section{MATERIAL AND METHODS}

\section{Transmitter}

Due to the difficulty in obtaining wild caught American bullfrogs, only nine adult bullfrogs were tagged with an internal transmitter and tracked during one year.

Only sexually mature frogs with a length of more than $11 \mathrm{~cm}$ snout to stout (BRUNEAU \& MAGNIN, 1980) and a weight over 180 gram were selected (Table 1) to gain insight into the dispersion and reproductive behaviour of adult individuals.

Implantable transmitters are most suitable because they interfere less than external transmitters with the long-term behaviour and lifespan of the animal (MIAUD et al., 2000). Radio-transmitters should not exceed more than $10 \%$ of the body mass of the animal, but many authors suggest an even more conservative limit of 5\% (RICHARDS et al., 1994). Therefore, the transmitter R1170 (ATS Inc., Isanti, MN, USA) was used. It has a weight of 4 grams and a lifespan of the battery of approximately 440 days. Pulse speed and -length was at 30ppm and $15 \mathrm{~ms}$ respectively. To localize the animals a 3-element Yagi antenna (Bluesky Telemetry, Perthshire, UK) and a R410 receiver (ATS Inc., Isanti, MN, USA) were used.

\section{Study area and implanting procedure}

Five male and four female adult American bullfrogs were caught in May 2011 with fykes $(0.8 \mathrm{~m}$ diameter, $1 \mathrm{~cm}$ mesh $)$ in the same pond in the valley of the Grote Nete $\left(51^{\circ} 8^{\prime} \mathrm{N}, 05^{\circ} 8^{\prime} \mathrm{E}\right)$ (Fig. 1). The eutrophic pond has a surface of $4,280 \mathrm{~m}^{2}$ where the shores are dominated by Phragmites australis, Typha latifolia, often with overhanging shoreline vegetation such as Rubus spec. and Carex spec. The surrounding habitat consists of alluvial forest with small puddles and larger ponds, crossed by the river Grote Nete.

The frogs were weighed and measured from snout to stout (Table 1) and anesthetised in tricaine methanesulfonate (MS-222, 2g/l). A ventral cut of $1 \mathrm{~cm}$ in the abdominal left side was made in the skin and abdominal muscles. The transmitter was placed in the intraperitoneal cavity; muscle layer and skin were each closed with four sutures of absorbable Monocryl-plus (Ethicon, Somerville, NJ, USA). Finally the wound, with sutures, was covered with Vetbond skin glue (3M, St.Paul, MN, USA). After surgery, the animals recovered for 30 minutes in 
fresh pond water and were released at the site of capture.

Before the start of this experiment, a dummy transmitter was implanted in adult bullfrogs under laboratory conditions to evaluate the impact of the procedure. The animals recovered well and showed no visible disadvantage from the implant. Internal examination of the animals one month post implantation showed that the dummy transmitter was encapsulated by connective tissue around the intestines of the animal and did not impede the functioning of any of the organs.
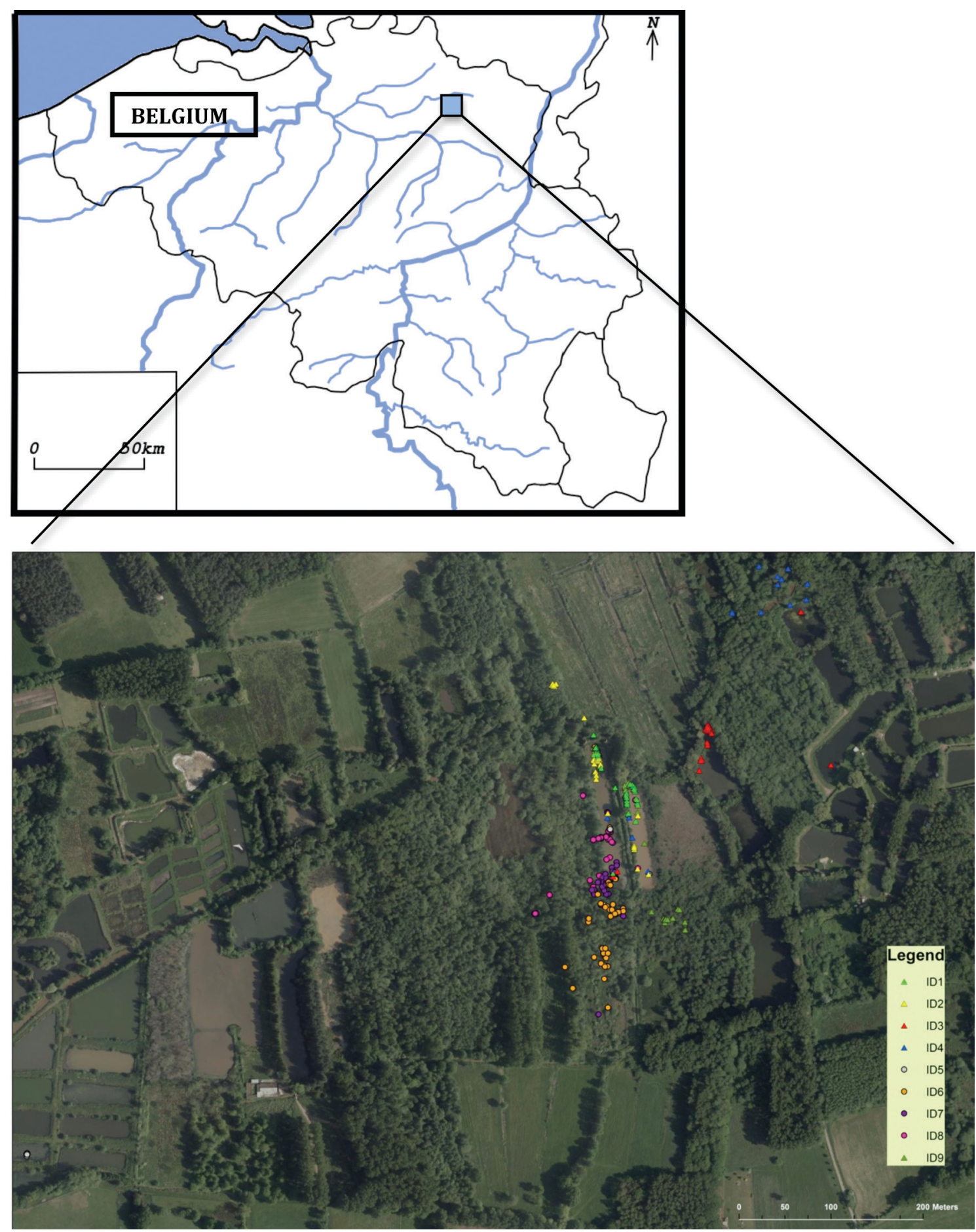

Fig. 1. - Localisation of the research area and the fixes of the tracked bullfrogs within the valley of the Grote Nete (ArcGIS 10). 
TABLE 1

Characteristics of the radio-tagged bullfrogs, start and end of tracking period and number of fixes per individual.

\begin{tabular}{ccccccc}
\hline Individual & Gender & Weight $(\mathbf{g})$ & Length $(\mathbf{c m})$ & Start date & End date & \# Fixes \\
\hline 1 & M & 196 & 12.9 & $12 / 05 / 11$ & $28 / 08 / 12$ & 136 \\
2 & M & 180 & 11.2 & $16 / 05 / 11$ & $04 / 07 / 12$ & 131 \\
3 & M & 492 & 16.5 & $17 / 05 / 11$ & $28 / 08 / 12$ & 139 \\
4 & M & 252 & 14 & $31 / 05 / 11$ & $28 / 08 / 12$ & 87 \\
5 & F & 348 & 13.2 & $12 / 05 / 11$ & $28 / 08 / 12$ & 10 \\
6 & F & 312 & 14.8 & $12 / 05 / 11$ & $28 / 08 / 12$ & 137 \\
7 & F & 202 & 11.7 & $12 / 05 / 11$ & $28 / 08 / 12$ & 137 \\
8 & F & 268 & 14 & $16 / 05 / 11$ & $25 / 07 / 12$ & 118 \\
9 & M & 298 & 14.7 & $31 / 05 / 11$ & $28 / 08 / 12$ & 134 \\
\hline
\end{tabular}

\section{Radio tracking}

During the months of May till September 2012 the position of each frog was determined by triangulation twice a week, alternately in the morning and the evening. This interval allowed an accurate estimation of home range in the fish Barbus barbus (LinNAEUs, 1758), which is a far more mobile species than the American bullfrog (BARAS, 1998). Every month a 24h-cycle was executed and frogs were tracked every hour, to get a better insight into total movements during day and night. From October till March, the period of winter torpor, the animals were localized once a month.

At the end of the tracking period, which lasted 16 months, only two animals could not be localized due to the life-end of the batteries (Table 1).

\section{Data analysis}

Data analysis was performed using ArcGIS Spatial Analyst 10 (Esri, Redlands, CA, USA) and HRT-tools for ArcGIS (RODGERS et al., 2007). To gain insight into the total area used by an animal the Minimal Convex Polygon 95\% (MCP95) was calculated. Moreover, Kernel Density Estimates 50\% (KDE50) and 95\%
(KDE95) were performed on the tracking results to define respectively the core range and home range of each individual bullfrog. For statistical analysis SPSS statistics 22 (IBM, Armonk, NY, USA) was used.

\section{RESULTS}

During the tracking period two individuals (nr. 4 and 5) were temporarily unable to be located, partly due to the inaccessibility of the habitat so fewer fixes were available (Table 1).

At the start there was no statistically significant difference in length and weight of the two sexes (Mann-Whitney $\mathrm{U}, p=0.905$ and $p=0.556$ respectively).

Most individuals remained in the area where they were caught, but some dispersed further into the surrounding landscape using permanent ponds and marshes in alluvial forest or the Grote Nete as a guide line (Fig. 1). Mean convex polygons (MCP95) were calculated for the different individuals, and revealed a mean $\pm \mathrm{SD}$ of $11,086.73 \pm 12,239.00 \mathrm{~m}^{2}$ of total area used by adult American bullfrogs. To have a better idea of the more exact home range of these individuals, KDE95 was calculated (Table 2). The mean home range was $429.78 \pm 510.97 \mathrm{~m}^{2}$, 
TABLE 2

Results of the Kernel density analysis with habitat type for KDE50 and MCP 95\% per individual. (A= permanent pond, $\mathrm{B}=$ swamp in alluvial forest).

\begin{tabular}{|c|c|c|c|c|c|}
\hline \multicolumn{5}{|c|}{ Fixed Kernel } & \multirow{3}{*}{$\frac{\text { MCP } 95 \%}{\text { Total range }\left(\mathrm{m}^{2}\right)}$} \\
\hline ID & Core range $\left(\mathbf{m}^{2}\right)$ & KDE50 & Home range $\left(\mathrm{m}^{2}\right)$ & \# of locations & \\
\hline & KDE50 & Habitat & KDE95 & KDE95 & \\
\hline 1 & 5.09 & $\mathrm{~A}$ & 65.86 & 17 & 1286.91 \\
\hline 2 & $11.06-15.24$ & $\mathrm{~A}$ & 365.21 & 9 & 3772.05 \\
\hline 3 & 62.43 & $\mathrm{~A}$ & 412.26 & 3 & 3656.12 \\
\hline 4 & $4.8-61.63$ & $\mathrm{~B}-\mathrm{A}$ & 1723.94 & 16 & 38413.84 \\
\hline 5 & 68.66 & $\mathrm{~A}$ & 148.72 & 1 & 23937.73 \\
\hline 6 & $\begin{array}{c}1.23-1.37-1.39- \\
3.08-5.61\end{array}$ & $\mathrm{~B}$ & 282.9 & 27 & 10455.06 \\
\hline 7 & $0.47-1.35$ & $\mathrm{~B}-\mathrm{A}$ & 59.67 & 25 & 5030.27 \\
\hline 8 & $10.37-13.11$ & B -A & 542.79 & 12 & 8128.63 \\
\hline 9 & $0.81-5.10-12.25$ & $A-A-B$ & 266.66 & 11 & 5099.93 \\
\hline $\begin{array}{c}\text { Mean } \pm \\
\text { SD }\end{array}$ & $22.64 \pm 26.18$ & & $429.78 \pm 510.97$ & & $\begin{array}{c}11086.73 \pm \\
12239.00\end{array}$ \\
\hline
\end{tabular}

with a mean of $13 \pm 9$ different locations used. To define the core ranges of the American bullfrogs KDE50 was determined (Table 2). Sixty seven per cent of the individuals showed more than one Kernel $50 \%$ position and the mean area was 15.0 $\pm 22.41 \mathrm{~m}^{2}$. The KDE50 habitats were examined and are either permanent ponds (habitat A) or swampy puddles in alluvial forest (habitat B) (Table 2).

Analysis of the MCP95, KDE50 and KDE95 showed no statistically significant differences in area occupied by male or female American bullfrogs (Mann-Whitney $\mathrm{U}, p=0.221, p=0.462$ and $p=0.462$ respectively). No statistically significant correlation was found between length, weight or sex of the individuals and their major choice of habitat, core and home range size.

To gain insight in the dispersion abilities of individual adult bullfrogs the total distance, maximal distance from point of release and maximal distance in a single movement were calculated (Table 3). The total distance travelled during the tracking period varied greatly between individuals, with a mean \pm SD of $1,152.23 \pm$ $348.56 \mathrm{~m}$. The maximal distance travelled from the release point had a mean \pm SD of $270.78 \pm$ $199.17 \mathrm{~m}$. Also the maximal distance covered in a single movement varied greatly between individuals and showed a mean \pm SD of 248.70 $\pm 202.34 \mathrm{~m}$ (Table 3 ). All the variables analysed in Table 3 varied greatly between individuals.

There was no statistically significant difference between sexes in the maximal distance from the point of release and in a single movement (MannWhitney $\mathrm{U}, p=0.806$ and $p=0.624$ respectively). No statistically significant correlation was found between length of the animal and maximal distance from point of release and distance travelled in a single movement (Spearman, $r=$ 0.433 and $r=0.360$ ). Weight of the bullfrogs was not correlated with maximal distance from point of release (Spearman, $r=0.142$ ), but a significant correlation was found with the maximal distance covered in one single movement (Spearman, $r=$ $0.683)$. 
TABLE 3

Overview distances per individual.

\begin{tabular}{cccc}
\hline Individual & Total distance $(\mathbf{m})$ & Max. distance from release point $(\mathbf{m})$ & Max. distance in a single movement $(\mathbf{m})$ \\
\hline 1 & 878.00 & 152.06 & 130.48 \\
2 & 1177.26 & 140.13 & 118.91 \\
3 & 1125.52 & 345.90 & 353.16 \\
4 & 1089.48 & 414.51 & 295.54 \\
5 & 814.08 & 726.54 & 742.21 \\
6 & 1818.31 & 145.59 & 135.61 \\
7 & 1621.98 & 233.61 & 167.71 \\
8 & 861.57 & 122.77 & 138.94 \\
9 & 983.85 & 155.93 & 155.71 \\
\hline \multirow{2}{*}{ Mean \pm SD } & $\mathbf{1 1 5 2 . 2 3} \pm \mathbf{3 4 8 . 5 6}$ & $\mathbf{2 7 0 . 7 8} \pm \mathbf{1 9 9 . 1 7}$ & $\mathbf{2 4 8 . 7 0} \pm \mathbf{2 0 2 . 3 4}$ \\
\hline
\end{tabular}

\section{DISCUSSION}

The KDE50 analysis shows that adult American bullfrogs in the valley of the Grote Nete had a core range (KDE50) with an average size of $15.00 \pm$ $22.41 \mathrm{~m}^{2}$. Habitats were located in the littoral zone of ponds or under bushes at the edge of pools or puddles in the alluvial forest. Some of the frogs temporarily changed location, which resulted in more than one KDE50 area for the specimen (Table 2, Fig. 2). A possible explanation is that individuals who had their core range within the alluvial forest, went to larger ponds during the reproductive season and returned to their initial spot later. This behaviour has also been observed in Southwest France where the bullfrogs reached the reproductive pond in June after spending two months in a flooded area (BERRONEAU et al., 2007). Moreover, within the summer feeding habitat the frogs may change position in search for food and shelter. The home ranges (KDE95) of the frogs in this study, composed of a number of distinct spots, suggest that they used different suboptimal habitats for shelter and foraging. During the 12 and 24 hours tracking sessions the individuals hardly moved, which can be explained by assuming that they found their food and shelter within their KDE95 spots and did not actively search for prey, especially in the ponds where bullfrog larvae and topmouth gudgeon
(Pseudorasbora parva TEMMINCK \& SCHLEGEL, 1846) prey were very abundant near the shelters.

The movements of the nine individual frogs revealed that only two types of habitats (Table 2) were used, one is the shoreline of the ponds dominated with Phragmites australis, Typha latifolia, with overhanging shoreline vegetation such as Rubus spec. and Carex spec. (habitat A). The other habitat consists of brooks with shallow pools or puddles within alluvial forest (habitat B). In a Canadian study, the mean activity radius, used as an index of home range size (in Ontario, Canada), was $21.40 \mathrm{~m}^{2}$ (CURRIE \& BELlis, 1969). The authors stated that the home range size may be reduced at high densities. In this Canadian study the bullfrog spots were almost all located in water in spite of occasional visits to land. These findings differ from our results of the adult bullfrogs in the valley of the Grote Nete, which have shown a home range (KDE95) of $429.78 \pm$ $510.97 \mathrm{~m}^{2}$. We should keep in mind that our study was carried out over a longer period than the onemonth one in Ontario (Canada). Moreover, the larger home range in our study also indicates a lower density in the examined area as documented by (CURRIE \& BELLIS, 1969) and/or a difference in behaviour between the frogs in Canada and Belgium. The density of American bullfrogs in adjacent ponds in the valley of the Grote Nete 
has been examined, and showed an estimate of 46 individuals/ha water surface (LOUETTE et al., 2013) while the bullfrogs in Ontario (Canada) had a density of 272-420 individuals/ha (CURRIE \& BELLIS, 1969). It is also possible that bullfrogs of an invasive population demonstrate increased dispersive behaviour.

Seasonal pools are a part of the bullfrog habitat complex, providing the population with food, refugium and stepping stones (GAHL et al., 2009). This author stated that the use of these pools varied for sex and age category, and that males were often found in seasonal pools before the reproduction season. This could not be confirmed from our study in the valley of the Grote Nete, where $60 \%$ of the males had their home range (KDE50) exclusively in permanent ponds and $40 \%$ in seasonal puddles and ponds. Additionally no significant correlation was noticed between the sex and the amount of KDE50 in the shorelines of permanent ponds. However, males examined in our preliminary study tended to prefer the shore of permanent ponds while females were equally divided between both habitats. Likewise, no statistical correlation was found between the area of a KDE50 spot and the amount of KDE50 spots in alluvial forest. However, a trend was notable, suggesting that smaller but more spots are occupied when the KDE50 habitat is located in alluvial forest. Possibly this is due to a lower abundance of food or quality of shelters in this alluvial forest compared to the shores of large permanent ponds. Further research on the movements of a higher number of adult bullfrogs with telemetry could give better insight in the habitat use of both sexes.

As for hibernation, a study in Summit County USA showed that the bullfrogs favour relatively shallow $(<1 \mathrm{~m})$ sites with algae and cattails, fed by small streams (STINNER et al., 1994). A habitat model made for the American bullfrog showed that the suitability of a wetland as winter cover can be expressed as a combination of the winter water depth and the relative amount of silt in the bottom substrates (GRAVES \& ANDERSON, 1987). Another telemetric study in France revealed that $80 \%$ of the individuals of the American bullfrog hibernated under mulch in wooded area (BERRONEAU et al., 2007). The habitat choice for hibernation in this study was equally divided among the individuals. Fifty per cent of the investigated bullfrogs favoured the littoral zone of large permanent ponds, while the others preferred the wet soil in the alluvial forest. During the winter period only one individual showed some smaller movements, but in general
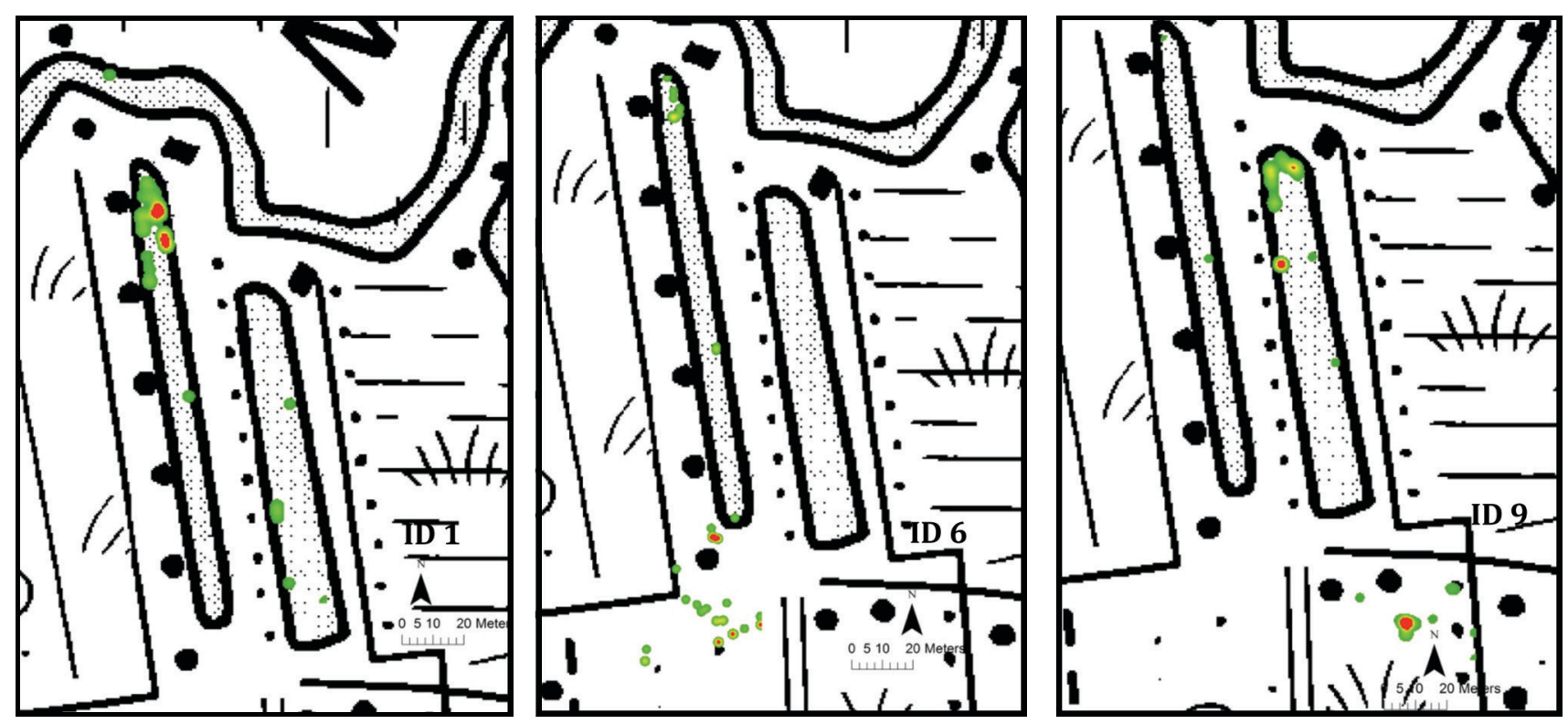

Fig. 2. - KDE50 and KDE95 locations (red and green, respectively) for the individual nr.1, 6 and 9 [see the online version for the colour figure]. 
the hibernation positions were maintained during this season. These winter localities correspond with the KDE50 positions, which suggests that the core range habitat is suited for both summer foraging and shelter as well as for winter hibernation. The fact that individuals showed movements during the cold season makes it clear that they are not fully torpid during the whole winter season, but that they probably have torpid periods alternated with short active moments so they can avoid unfavourable conditions or forage. In Southwest France several individuals were reported active during winter and they carried out important movements (BERRONEAU et al., 2007).

Analysis of the movements made by the tracked adult bullfrogs in our study show that long distances can be covered in search of suitable habitats. During one week, some individuals moved up to $742 \mathrm{~m}$ (Table 3 ) but the average activity radius in this study had a mean \pm SD of $270.78 \pm 199.17 \mathrm{~m}$, which shows that there was a high variability among the adult individuals. On a yearly basis a frog could move up to a maximum total distance of $1,818 \mathrm{~m}$ (Table 3). Studies in New York and Missouri (USA) showed that bullfrogs can move from 1,200 to $1,600 \mathrm{~m}$ in one year (INGRAM \& RANEY, 1943; WILLIS et al., 1956). This corresponds with our findings and suggests that the environmental circumstances within the valley of the Grote Nete are similar to the studied territories in the USA. These results show that dispersion of this invasive species within an ecosystem such as the valley of the Grote Nete can proceed very rapidly, which is confirmed by unpublished data on a public website (NATUURPUNT VZW, 2006). Adult and sub-adult bullfrogs also use rivers as a dispersion route (PETERSON et al., 2013) as confirmed by findings in our study where some individuals used and crossed the river in search of food and shelter. A female biased dispersion in bullfrogs is reported, where the males have a tendency to return to their birthplace with local reproductive resources (AUSTIN et al., 2003). A wider female dispersal can be expected because of the lack of parental care and the importance of mate choice in inbreeding avoidance and reproductive success (AUSTIN et al., 2003). A shorter multiple mark - recapture study in other pools in the valley of the Grote Nete found a substantial difference between adult male and female bullfrogs during the reproduction period (LOUETTE et al., 2013). However, these results could not be confirmed in our study, as no statistically significant difference was found between the movements made by males or females.

During the 24h-cycle trackings in the reproductive season most of the tracked frogs hardly changed position. Given that the larger ponds, where the animals were tracked, all had a very high abundance of larvae there must have been successful reproductions of the bullfrog. Our results suggest that reproductive movements are at short intervals during specific climatological circumstances. Daily tracking during this season would give better insight into the determining factors for reproductive migration. Overall weekly movements did occur during this period, which indicate that individuals moved back and forth to the reproduction sites. This migratory pattern was also observed in a pond in New Jersey (USA), where, during the breeding season, the movements from and to the pond were linked to environmental conditions such as rainfall and an elevation of the air temperature (RYAN, 1980). In our study, the movements towards the larger permanent ponds during the reproductive season were not simultaneous for all individuals that had a KDE50 in the alluvial forest. The period in which the males inhabited the permanent pond was longer than for the females. Three of the five tracked males in this study occupied a specific spot at the permanent ponds that also function as reproductive sites. The females shared more variations in positions during this period. These observations may confirm the fact that females arrive at asynchronous intervals at the breeding pond during the reproduction period because the duration of sexual activity for an individual female is extremely short, generally only one night (RANEY, 1940; EMLEN, 1976; RYAN, 1980). These findings suggest that males, as in 
the majority of amphibians, defend and hold their optimal reproduction site for a long time and females migrate to the pond for a shorter time to choose a mating partner and reproduce. This "resource defence polygyny" (EMLEN \& ORING, 1977) was also observed in a study at New Jersey, which showed that the males actively defended the oviposition sites in the ponds (RYAN, 1980). During a few nights in the mating season males form short-term calling aggregations, also called choruses. This spatial organisation reflects the social dominance of the males in the population. They aggregate for the purpose of attracting females, and females move actively to the choruses and select their mating partner (EMLEN, 1976). EMLEM (1976) also stated that, during mating season, males are highly mobile and move from one aggregation to another. Moreover, as shown by RANEY (1940), the movements took place after sunset and during or after rainfall and were not correlated with foraging, egg-laying or temperature changes. A higher mobility of male adult bullfrogs could not be confirmed in our study in which males stayed at their specific spot during the reproduction period. A possible explanation for this phenomenon is that those male aggregations are very rare or unique in a specific pond and consequently so also are the movements towards it. The frequency or time of tracking adopted in this study did not record these brief displacements. GPS-telemetry would be a better option to track these movements in the future, but suitable GPS-transmitters were not available at the time of the study.

The analyses of the distances covered by the adult bullfrogs during the tracking period revealed a statistically positive correlation between the weight of the animal and the maximal distance covered during one displacement event. This suggests that heavy and consequently dominant animals tend to search more for an optimal habitat for reproduction, foraging, hibernation and shelter.

The present conservation plans and measures for SAC in the valley of the Grote Nete focus on rewetting and creating wet corridors between the different parts of the valley (AGENTSCHAP VOOR NATUUR EN Bos, 2012). Considering the results from this study, these plans will favour and enhance the dispersion of this invasive species and create more suitable habitats as well. The marsh habitat characteristics of this large ecosystem and the fact that the population is already widely spread (distance of $42 \mathrm{~km}$ in the valley), impede an active control of the populations of the American bullfrog in this valley. Such active control methods include removing adults, sub-adults and especially larvae with fykes and are the only measures taken at the moment. Therefore, passive control systems are urgently needed in these conditions in order to reduce the high local impact of this invasive species on the native species. A possible strategy is the use of the 'Sterile-Male-Release'-technique (PATTERSON et al., 1968). This technique is a structural and sustainable method to eradicate or control large population of invasive exotic species. The release of a high number of sterile males of the invasive species is necessary to reduce the amount of successful fertilizations. In the male sea lamprey (Petromyzon marinus LINNAEUS, 1758) the sterility does not affect the mating instinct and competitive behavior (BERGSTEDT \& Twohey, 2007). The release of sex pheromones is not inhibited either, so ovulating females will still be attracted (BERGSTEDT \& TwOHEY, 2007). A combination of removal of female sea lampreys by traps and the sterile male release resulted in an average population reduction of $64 \%$ over eight years in the Great Lakes region (US) (BERGSTEDT et al., 2003).

More research is needed into the development of sustainable, cost effective and laborextensive techniques to control widely extended populations of bullfrogs or other invasive alien species. Trapping adults combined with functional sterility of male individuals, and their subsequent release, could provide a longterm solution to control these types of invasive populations. 


\section{CONCLUSIONS}

The dispersion of the invasive American bullfrog proceeds very rapidly in a river ecosystem such as the valley of the Grote Nete (Belgium). This study showed a statistically significant correlation between the weight of the animal and the distance they covered in a single movement, suggesting that more dominant animals will disperse faster in the surrounding landscape. The tracked bullfrogs had a small core range habitat with high spot fidelity, which provided them with food and shelter in the shoreline of permanent ponds or the alluvial forest. An effective method is needed to control the wide dispersion of this invasive species in the valley of the Grote Nete to safeguard the local biodiversity in this SAC.

\section{ACKNOWLEDGEMENTS:}

This study was financed by the EU Interreg IV A project IVA-VLANED-2.31 "Invasieve exoten in Vlaanderen en Zuid-Nederland-INVEXO" and the PWO-project "EXOUT" of University College PXL.

We would like to thank numerous students who helped in the field and the steering committees of the projects mentioned above. We are also grateful to the referees for their constructive input.

Ethical approval: All applicable national and institutional guidelines for the care and use of animals were followed (approval number 201024).

\section{REFERENCES}

AdAms JM \& Pearl CA (2007). Problems and opportunities managing invasive Bullfrogs: is there any hope? In: GHERARDI F (eds), Biological invaders in inland waters: profiles, distribution and threats, Springer, The Netherlands: 679-693.

AgENTSCHAP VOOR NATUUR EN BOS (2012): Instandhoudingsdoelstellingen voor speciale beschermingszones - Bovenloop van de Grote
Nete met Zammels broek, Langdonken en Goor, vol BE2100040 p. 254.

Austin JD, Davilla JA, LOUgheEd SC \& BOAG PT (2003). Genetic evidence for female-biased dispersal in the bullfrog, Rana catesbeiana (Ranidae). Molecular Ecology, 12: 3165-3172.

BARAS E (1998). Selection of optimal positioning intervals in fish tracking: an experimental study on Barbus barbus. Hydrobiologia, 371/372: 19-28.

Bergstedt RA, McDonald RB, Twohey MB, MuLLET KM, YOUNG BA \& HEINRICH JW (2003). Reduction in sea lamprey hatching success due to release of sterilized males. Journal of Great Lakes Research, 29: 435-444.

BERGSTEDT RA \& TwOHEY MB (2007). Research to support sterile-male-release and genetic alteration techniques for sea lamprey control. Journal of Great Lakes Research, 33: 48-69.

BERroneau M, DÉtaint M \& CoÏC C (2007). Premiers résultats du suivi radio télémétrique de la Grenouille taureau en Gironde (septembre 2004juin 2005). Bulletin de la Société Herpétologique de France, 121: 21-33.

BRUNEAU M \& MAGNIN E (1980). Croissance, nutrition et reproduction des ouaouarons Rana catesbeiana Shaw (Amphibia Anura) des Laurentides au nord de Montréal. Canadian Journal of Zoology, 58: 175-183.

Clavero M \& Garcia-Berthou E (2005). Invasive species are a leading cause of animal extinctions. Trends in Ecology and Evolution, 20: 110.

CURRIE W \& BeLlis ED (1969). Home range and movements of the bullfrog, Rana catesbeiana Shaw, in a Ontario Pond. Copeia, 4: 688-692.

D'AMORE A (2012). Rana (Lithobates) catesbeiana Shaw (American bullfrog). In: FRANCIS R A (eds), A handbook of global freshwater invasive species, Earthscan, Taylor \& Francis Group, Abingdon, USA: 321-330.

EMLEN ST (1976). Lek organisation and mating strategies in the bullfrog. Behavioral Ecology and Sociobiology, 1: 283-313.

EMLEN ST \& ORING L (1977). Ecology, sexual selection, and the evolution of mating systems. Science, 197: 215-233.

Fuller TE, Pope KL, Ashton DT \& Welsh HHJ (2010). Linking the distribution of an invasive amphibian (Rana catesbeiana) to habitat conditions in a managed river system in Northern California. Restoration Ecology, 19: 204-213. 
GaHL MK, CALHOUn AJK \& GRaVES R (2009). Facultative use of seasonal pools by American bullfrogs (Rana catesbeiana). Wetlands, 29: 697703.

GRAVES BM \& ANDERSON SH (1987): Habitat suitability index models: bullfrog, vol Biological Report 82.

INGRAM WM \& RANEY EC (1943). Additional studies on the movement of tagged bullfrogs, Rana catesbeiana Shaw. The American Midland Naturalist, 29: 239-241.

JENNINGS MR \& HAYES MP (1985). Pre-1900 overharvest of California Red-legged frogs (Rana aurora draytonii): the inducement for Bullfrog (Rana catesbeiana) introduction. Herpetologica, 41: 94-103.

LeIVAs PT, LEIVAS FWT \& MOURA MO (2012). Diet and trophic nice of Lithobates catesbeianus (Amphibia: Anura). Zoologia, 29: 405-412.

LOUetTe G, DeVisSCHER S \& AdRIAENS T (2013). Controle of invasive American bullfrog Lithobates catesbeianus in small shallow waterbodies. European Journal of Wildlife, 59: 105-114.

Lowe S, Browne M, Boudjelas S \& De Poorter M (2000). 100 of the world's worst invasive alien species. A selection from the global invasive species database. Aliens, 12: 1-12.

Miaud C, SANUY D \& AVRILLIER J (2000). Terrestrial movements of the natterjack toad Bufo calamita (Amphibia, Anura) in a semi-arid, agricultural landscape. Amphibia-Reptilia, 21: 357-369.

NATUURPUNT VZW (eds). 2006. Waarnemingen. (Internet address: http://www.waarnemingen.be).

PASMANS F \& MARTEl A (2012). Schimmel- en virusonderzoek, pathologie. In: INBO (eds), Beheer van Stierkikker in Vlaanderen en Nederland, Instituut voor Natuur en Bosonderzoek, Brussel: 93-94.

PATTERSON RS, LOFGREN CS \& BOSTON MD (1968). The sterile-male technique for control of mosquitos: a field cage study with Anopheles quadrimaculatus. The Florida Entomologist, 51: 77-82.
Peterson AC, Richgels KLD, Johnson PTJ \& MCKenZIE VJ (2013). Investigating the dispersal route used by an invasive amphibian, Lithobates catesbeianus, in human-dominated landscapes. Biological Invasions, 15: 2179-2191.

RANEY EC (1940). Summer movements of the bullfrog, Rana catesbeiana Shaw, as determined bij the jaw-tag method. American Midland Naturalist, 23: 733-745.

RICHARDS SJ, SINSCH U \& ALFORD RA (1994). Radio Tracking. In: HEYER W R, DONNELLY M A, MCDiARMid R W, HAYEK L C, Foster M S (eds), Measuring and Monitoring Biological Diversity: Standard Methods for Amphibians, Smithsonian Institution Press, Washington: 155-157.

Rodgers AR, CARr AP, Beyer HL, SMITH L \& KIE JG (2007): HRT: Home Range Tools for ArcGIS, Version 1.1. Ontario Ministry of Natural Resources, Centre for Northern Forest Ecosystem Research, Thunder Bay, Ontario, Canada.

RYAN MJ (1980). The reproductive behavior of the bullfrog (Rana catesbeiana). Copeia, 1: 108-114.

Schloegel LM, Ferreira CM, James TY, Hipolito M, LONGCORE JE, HYATT AD, YABSLEY M, MARTINS AMCRPF, MAZZONI R, DAVIES AJ \& DASZAK P (2010). The North American bullfrog as a reservoir for the spread of Batrachochytrium dendrobatidis in Brazil. Animal Conservation, 13: 53-61.

StinNer J, Zarlinga N \& ORCUTt S (1994). Overwintering behavior of adult bullfrogs, Rana catesbeiana, in Northeastern Ohio. Ohio Journal of Science, 94: 8-13.

Willis YL, MOYLE DL \& BASKeTT TS (1956). Emergence, breeding, hibernation, movements and transformation of the bullfrog, Rana catesbeiana, in Missouri. Copeia, 1: 30-41.

Received: 15 February 2016

Accepted: 2 June 2016

Branch editor: Zjef Pereboom 